\title{
KOTAK-KONTAK PINTAR PADA RUMAH CERDAS BERBASIS TEKNOLOGI INTERNET OF THINGS
}

\author{
Taufik Akbar', Gede Suweken², Gede Indrawan ${ }^{3}$, Kadek Yota Ernanda Aryanto ${ }^{4}$ \\ 1),3),4)Program Studi IImu Komputer, Pascasarjana, Universitas Pendidikan Ganesha \\ 2)Jurusan Matematika, FMIPA, Universitas Pendidikan Ganesha \\ E-mail: aliakbar.akbar266@gmail.com ${ }^{1}$, gede.suweken@undiksha.ac.id² ${ }^{2}$, gindrawan@undiksha.ac.id $^{3}$, \\ yota.ernanda@gmail.com ${ }^{4}$
}

\begin{abstract}
ABSTRAK
Penelitian ini bertujuan untuk merancang kotak kontak pintar pada rumah cerdas berbasis teknologi internet of things (IOT) guna untuk memonitor jumlah konsumsi daya perangkat elektronik pada rumah tangga. Sensor yang digunakan adalah 3 buah sensor arus AC N25 dan 1 buah sensor tegangan ZMPT101B, Arduino Nano dan Raspberry Pi yang digunakan dalam pemrosesan data, display 2×16 serta web server sebagai tampilan hasil dari konsumsi daya. Adapun pengujian dilakukan menggunakan 3 perangkat elektronik rumah tangga yaitu setrika, kipas Angin dan Satu buah televisi. Terdapat penurunan kemampuan pada sensor arus AC N25 dengan perubahan nilai berkisar 0.7-1 A sehingga harus dilakukan kalibrasi ulang. Perbedaan hasil pengukuran tegangan AC (220 VAC) yang dihasilkan sensor tegangan ZMPT101B, alat ukur Multimeter UT dan alat ukur digital multimeter kyoritsu. Namun perbedaan yang terjadi hanya pada rentang 5 VAC, sehingga dapat disimpulkan bahwa alat yang dirancang sudah sesuai dengan tegangan yang ada. Jumlah konsumsi daya kotak-kontak pintar pada rumah cerdas ini sendiri adalah pada sensor arus 0.125 Watt, sensor tegangan 0.001 Watt dan Arduino Nano 0.2 Watt.
\end{abstract}

Kata kunci: Kotak kontak pintar, rumah cerdas, internet of things, Raspberry Pi, Arduino

\begin{abstract}
This study aims to design a smart contact box in an internet of things (loT) technology-based smart home, in order to monitor the amount of power consumption of electronic devices within households. The sensors that were used consists of 3 AC N25 current sensors and 1 ZMPT101B voltage sensor, Arduino Nano and Raspberry Pi 3 which were used for data processing, 2x16 displays and web pages for displaying the results of power consumption of all contact box. The testing was carried out using 3 household electronic devices, namely an iron, a fan and a television. There was a decrease related to the ability of the AC N25 current sensor with changes in values, ranging from 0.7-1 $A$ so recalibration was required. The difference in the results of $A C$ voltage measurement (220 VAC) produced by the ZMPT101B voltage sensor, UT Multimeter measuring instrument and digital multimeter Kyoritsu measuring instrument. However, the differences that occured was only in the range of 5 vac. Therefore, we could concluded that the tool designed was in accordance with the existing voltage. The amount of smart contact-box power consumption in this smart home itself was 0.125 Watt on the current sensor, 0.001 Watt on voltage sensor and 0.2 Watt for the Arduino Nano.
\end{abstract}

Keywords : Smart contact box, smart home, internet of things, raspberry Pi, Arduino

\section{PENDAHULUAN}

Indonesia merupakan salah satu negara yang boros dalam pemakaian listrik di lingkungan negara-negara ASEAN berdasarkan data yang diperoleh dari ASEAN Centre for Energy (ACE) [1]. Namun demikian, disebutkan pula bahwa Indonesia memiliki potensi dalam melakukan penghematan tenaga listrik apabila perilaku boros yang terjadi selama ini dapat ditangani dengan baik. Terlebih, pasokan listrik di Indonesia sendiri tidak lagi dalam posisi yang baik dikarenakan cadangan yang 
tersedia tidak mampu mencukupi keseluruhan kebutuhan daya listrik bagi seluruh masyarakat. Lebih jauh, Indonesia masih akan menjadi negara pengkonsumsi energi terbesar yang diakibatkan oleh populasinya [2].

Pemborosan umumnya terjadi disebabkan oleh beberapa faktor, antara lain perilaku/gaya hidup masyarakat, kemampuan daya beli masyarakat, serta manajemen energi [3]. Pemborosan dapat terjadi dikarenakan banyaknya tempat tinggal yang penyerapan energinya tinggi walaupun tingkat kepenghuniannya dalam rumah atau ruang tersebut rendah. Hal ini terkadang terjadi karena ketidakdisiplinan terhadap penggunaan perangkat-perangkat listrik, seperti membiarkannya tetap bekerja walaupun tidak digunakan dalam rumah atau ruang tersebut. Selain itu, keborosan juga dapat terjadi dikarenakan ketidakawasan penghuni terhadap perangkat-perangkat listrik yang tidak bekerja dengan baik lagi. Perangkat semacam ini sudah tentu tidak mengkonsumsi energi listrik secara normal lagi.

Upaya-upaya terkait penghematan energi telah banyak diupayakan melalui pemanfaatan teknologi khususnya berbasiskan jaringan yang telah berkembang dewasa ini, salah satunya teknologi internet of things (IoT) [4]. Teknologi loT berkembang sebagai sebuah konsep yang bertujuan untuk memanfaatkan secara luas konektivitas jaringan komputer, khususnya internet, dalam implementasi aktivitas sehari-hari tanpa batas waktu. Implementasi loT yang sangat dekat dengan keseharian kita adalah rumah cerdas [5][6][7]. Teknologi rumah cerdas sendiri merupakan salah satu implementasi loT yang saat ini mulai banyak dimanfaatkan untuk berbagai kebutuhan otomasi dalam rumah. Rumah cerdas sendiri merupakan perpaduan antara teknologi informasi dan teknologi komputasi di mana efisiensi, otomasi perangkat, kenyamanan, keamanan serta penghematan merupakan faktor penting dalam implementasinya [7][8][9]. Saat ini, teknologi loT telah banyak diimplementasikan dengan berbasiskan pada integrasi dengan produk teknologi lainnya, seperti pemanfaatan teknologi berbasis pengontrol mikro [10][11][12].

Solusi rumah cerdas dalam usaha penghematan konsumsi energi listrik dalam rumah tangga sangat tepat untuk era disrupsi saat ini. Dalam penelitian ini, dibangun sebuah prototipe berupa kotak kontak pintar yang mampu memantau penggunaan listrik oleh perangkat-perangkat elektronik dalam rumah tangga dan mengirimkannya ke perangkat yang bertindak sebagai server pemantauan perangkat dengan tampilan laman berbasis web yang dapat diakses oleh penghuni. Oleh sebab itu, penghuni mampu mengetahui kinerja perangkat elektronik serta dapat melakukan tindakan terkait perangkat elektronik yang mengalami masalah atau yang tidak dibutuhkan melalui kontrol jarak jauh tanpa terbatas oleh ruang dan waktu.

\section{METODE}

Penelitian ini dilakukan melalui beberapa tahapan yang menggunakan konsep dasar metode pengembangan purwarupa berbasis iterasi dan inkremental [13][14]. Namun dalam hal ini, metode yang digunakan diaplikasikan pada pengembangan baik perangkat keras dan juga perangkat lunaknya. Secara umum, metode ini dapat dilustrasikan seperti pada Gambar 1 di bawah.

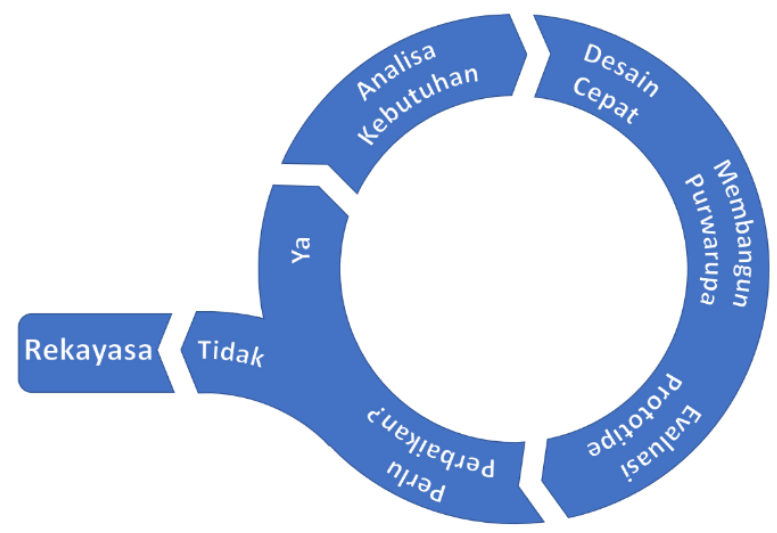

Gambar 1. Siklus yang dilakukan dalam metode iterasi 
Metode diawali dengan perencanaan, dalam hal ini baik perangkat keras maupun perangkat lunak. Perencanaan perangkat tersebut bertujuan untuk memberikan arah yang jelas dalam proses pengembangan tersebut nantinya. Dari perencanaan tersebut, proses pengembangan dilakukan dalam sebuah siklus. Siklus yang terjadi diawali dengan adanya pencermatan terhadap kebutuhan dalam pengembangan, baik masing-masing perangkat keras maupun perangkat lunak. Setelah perencanaan dan kebutuhan akan pengembangan telah diidentifikasikan maka fase berikutnya adalah fase desain dan analisis yang diikuti dengan implementasi dari apa yang telah dirancang tersebut. Purwarupa akan diuji dan dievaluasi terkait keberhasilan implementasinya. Dari hasil uji dan evaluasi tersebut, siklus akan berulang hingga sebuah produk purwarupa yang siap digunakan dapat diperoleh.

Dalam penelitian ini sendiri, terdapat dua siklus yang masing-masing berfokus pada pengembangan perangkat keras diikuti dengan pengembangan perangkat lunak. Adapun tahapantahapan yang dilakukan dalam pengembangan kedua perangkat dapat digambarkan menggunakan diagram alir pada Gambar 2 di bawah ini.

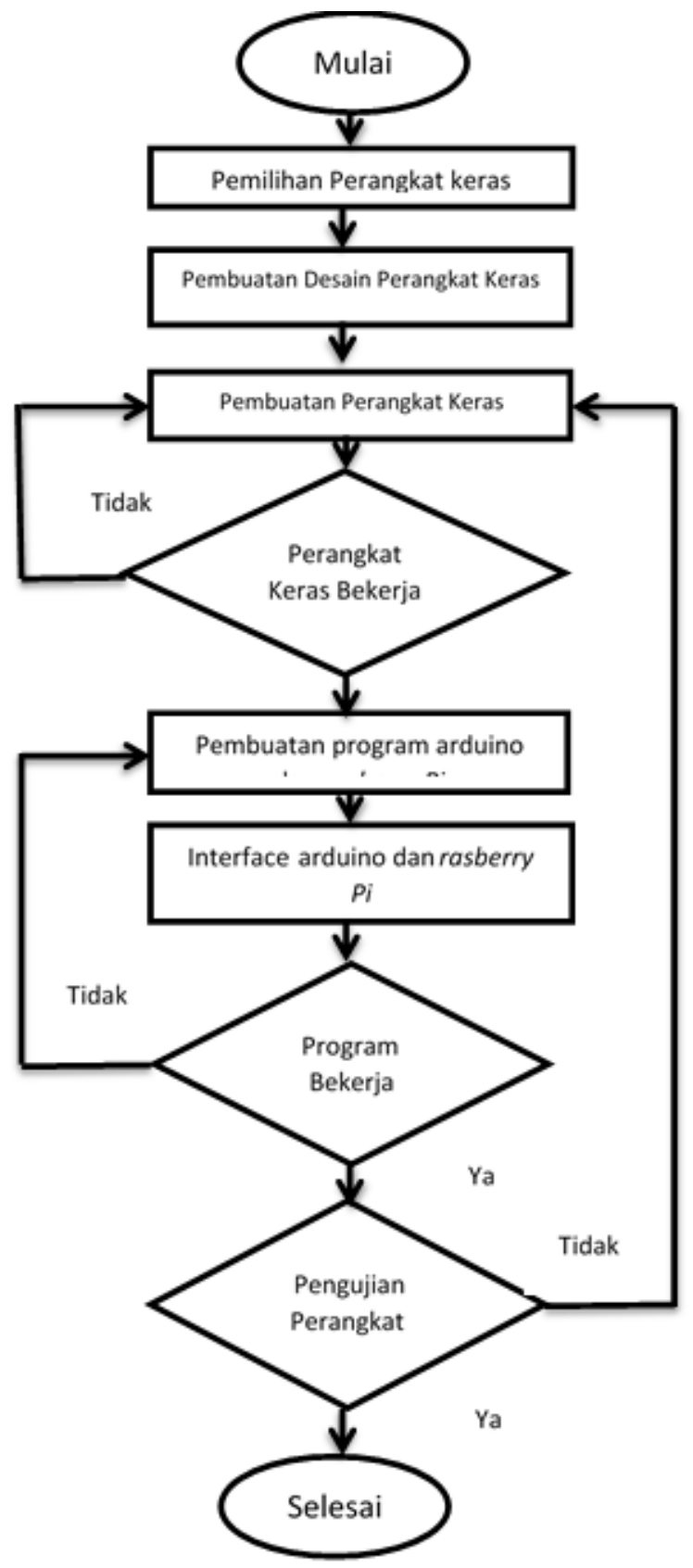

Gambar 2. Siklus yang dilakukan dalam metode iterasi 
Dari gambar tersebut jelas terlihat bahwa siklus pengembangan perangkat lunak mengikuti siklus pengembangan perangkat keras. Namun, pada akhir siklusnya, kemampuan perangkat lunak untuk dapat menjalankan proses sesuai dengan kinerja perangkat keras akan diuji dan dievaluasi kembali. Bila produk purwarupa telah sesuai dengan yang dibutuhkan, maka siklus akan berakhir. Sementara bila kinerja perangkat keras dan lunak tidak sesuai dengan yang diharapkan, maka penyesuaian perangkat keras akan dilakukan melalui siklus pertama.

\section{HASIL DAN PEMBAHASAN}

Dari pemaparan yang disampaikan dalam metode di atas, dilakukan implementasi terhadap kedua siklus tersebut. Dalam pengembangan perangkat keras, terdapat beberapa hal yang dilakukan, meliputi pemilihan perangkat keras, pembuatan desain, perancangan dan implementasi perangkat keras, serta pengujian terhadap kinerja sistem yang dibuat.

Pemilihan perangkat keras memiliki tahapan pemilihan komponen serta pemilihan sensor yang akan digunakan. Dalam penelitian ini, terdapat dua sensor yang dimanfaatkan yaitu sensor tegangan ZMPT101B dan sensor arus AC N25 dengan menggunakan tampilan 2x16. Untuk perangkat pemrosesan, dipilih Arduino Nano dan Raspberry Pi 3 serta sebuah relai untuk perangkat kontrolnya. Pembuatan desain dilakukan untuk menentukan tata letak perangkat keras yang akan digunakan guna mempermudah penggunaan perangkat. Setelah dilakukan tahapan pemilihan perangkat keras dan desainnya, maka selanjutnya implementasi dilakukan sesuai dengan desain.

Sensor arus yang digunakan dalam penelitian ini membutuhkan rangkaian penyedia tegangan berupa tegangan $5 \mathrm{v}$ dengan dibantu resistor sebagai pembagi serta membatasi aliran listrik. Adapun skema rangkaian penguat arus tersebut dapat dilihat pada Gambar 3 di bawah.

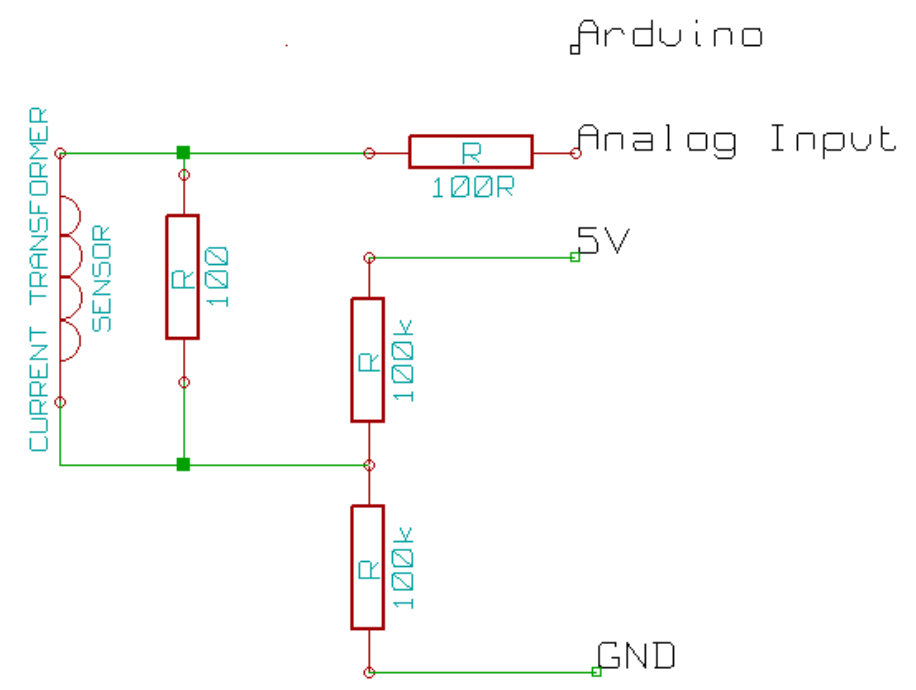

Gambar 3. rangkaian penguat sensor arus AC N25

Penggunaan sensor arus terlebih dahulu harus melewati uji kalibrasi karena sensor arus belum distandarkan. Adapun kalibrasi dilakukan dengan cara memasang sensor arus dengan tanpa beban. Adapun hasil kalibrasi yang diperoleh berbeda-beda dengan rentang antara $0.20-0,60$. Dengan hasil yang berbeda-beda ini, maka akan menyulitkan apabila kalibrasi harus dilakukan secara manual. Oleh sebab itu, dalam pengembangan bagian perangkat lunaknya, disertakan implementasi kalibrasi secara otomatis. Setelah beberapa kali penggunaan kekuatan ke 3 sensor mulai menurun dengan nilai kalibrasi yang berbeda, nilai diambil hanya pada 7 detik awal pemasangan sensor dengan perubahan berkisar pada rentang $0.75 \mathrm{~A}$ hingga $1 \mathrm{~A}$. Sementara itu, sensor tegangan berfungsi untuk mengukur jumlah tegangan AC. Digunakannya sensor tegangan pada penelitian ini karena di Indonesia, tegangan AC tidak konstan untuk berada pada nilai 220 VAC seperti yang telah dijelaskan di atas.

Siklus pengembangan perangkat lunak dilakukan setelah proses implementasi perangkat keras telah selesai dilakukan. Perancangan dilakukan untuk dapat menyesuaikan kebutuhan proses terkait dengan sensor-sensor yang digunakan. Program ditanam pada Arduino Nano menggunakan Ide 
Arduino dan Raspberry Pi. Program pada Arduino hanya membaca masukan yang berupa sinyal analog dari sensor tegangan dan arus kemudian menampilkan hasil pada LCD 2x16. Program pada Raspberry Pi menghubungkan hasil dari Arduino Nano ke perangkat layanan web.

Pada penelitian ini, penambahan Raspberry $\mathrm{Pi}$ ditujukan untuk menghubungkan perangkat pengukur beban ke sistem kontrol berbasis loT. Antarmuka Arduino Nano dan Raspberry Pi adalah berbasis bahasa pemrograman PHP: Hypertext Preprocessor (PHP) [15]. Sementara itu, sistem operasi yang digunakan dalam penelitian ini di dalam perangkat Raspberry Pi adalah Raspbian [16] yang telah dilengkapi dengan instalasi pelayan web Apache2 [17]. Adapun tampilan laman web untuk pemantauan konsumsi energi dapat dilihat dalam mode angka maupun grafis, seperti terlihat pada Gambar 4 di bawah.

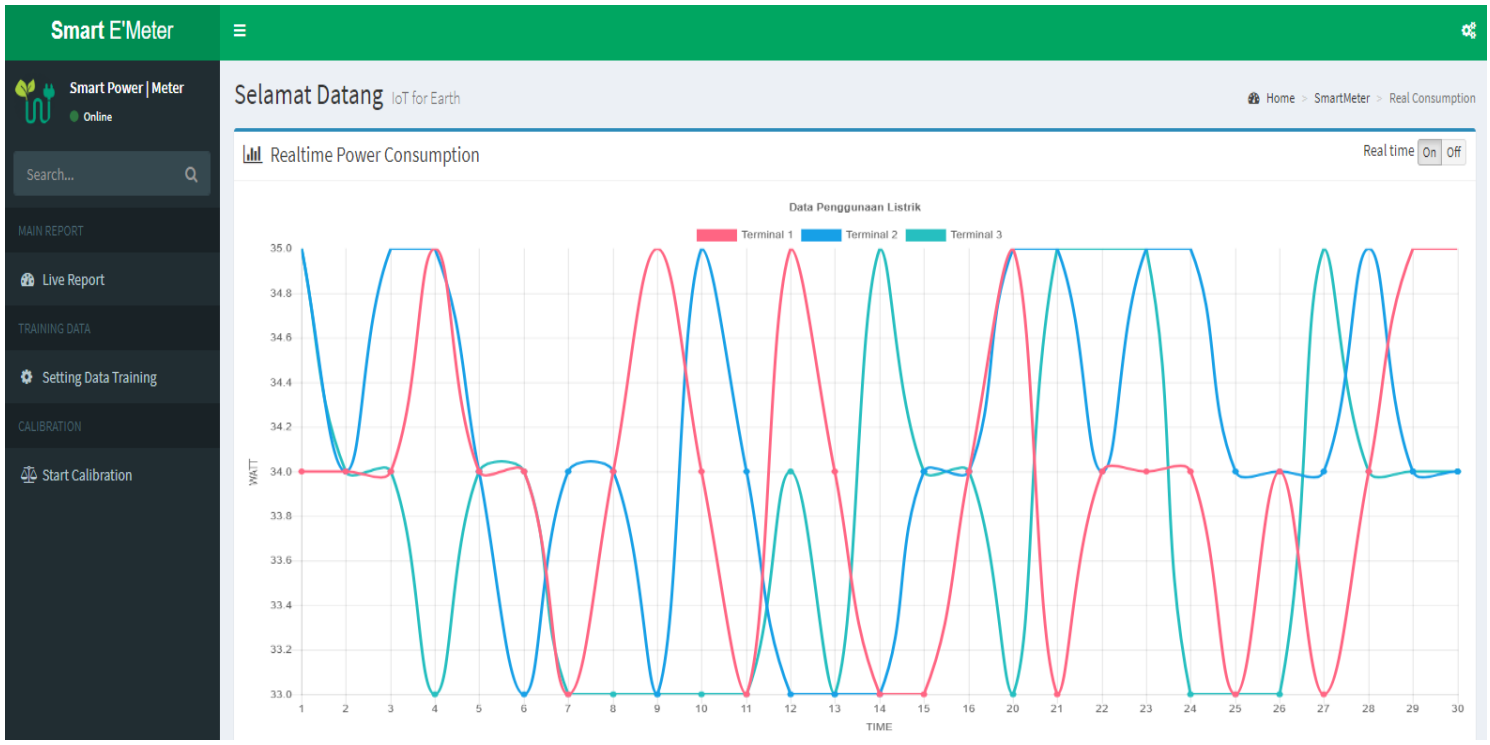

Gambar 4. Tampilan dalam mode grafis pemantauan penggunaan arus oleh tiga perangkat

Pengujian sistem dilakukan dengan mengukur beberapa beban apakah hasil sudah sesuai dengan nilai standar (hasil ukur dari multimeter UT890).

Dari pengembangan yang dilakukan, diperoleh sebuah alur proses yang dapat disebutkan sebagai berikut:

a) Sumber listrik PLN 1 fasa masuk ke kWh meter

b) Arus melewati sensor tegangan

c) Sensor arus dipasang pada satu jalur kabel ke kotak-kontak

d) Selanjutnya dihubungkan ke beban listrik yang digunakan

e) Hasil pembacaan sensor tegangan dibaca oleh Arduino Nano

f) Data string Arduino Nano dikirim ke Raspberry Pi

Selanjutnya Raspberry $\mathrm{Pi}$ merupakan perangkat di mana aplikasi untuk menyimpan hasil pemantauan ke dalam basis data dan menampilkannya ke laman web. Dengan demikian, aplikasi yang dibuat dapat diakses melalui perangkat komputer seperti komputer desktop, laptop, maupun perangkat bergerak.

Pengujian dilakukan untuk dapat mencermati apakah suatu perangkat atau purwarupa yang dihasilkan sudah dapat dijalankan sesuai dengan standar tertentu. Standar yang dijadikan acuan dapat berupa menurut instansi tertentu ataupun disesuaikan dengan keperluan pengguna. Pada penelitian ini standar biaya dari Perusahaan Listrik Negara (PLN) digunakan, sesuai dengan daya kilowatt-hour ( $\mathrm{kWh}$ ) yang digunakan oleh pengguna. Adapun dalam pengujian sistem, beberapa hal berikut dilakukan:

a) Menyesuaikan hasil pengukuran arus yang terukur oleh produk dengan alat ukur yang sudah standar (Multimeter UT 890)

b) Menyesuaikan hasil pengukuran tegangan yang terukur oleh produk dengan alat ukur yang sudah standar (Multimeter UT 890) 
c) Pengujian produk dengan perangkat sesuai dengan tujuan penelitian yaitu menghitung nilai daya beban dengan indikator konsumsi daya perangkat sesuai kapasitas produksi

Tahap pertama yang dilakukan adalah melakukan pengukuran terhadap tegangan listrik dari sumber daya yang digunakan. Dari proses yang telah dilakukan, diperoleh hasil berupa tegangan, arus dan daya yang didapatkan menggunakan produk yang telah dibuat berdasarkan penjelasan yang telah disampaikan sebelumnya. Pengukuran tegangan listrik dilakukan dengan menggunakan sensor ZMPT101B dengan 3 terminal pengukuran. Hasil yang diperoleh menunjukkan tegangan didapatkan berbeda-beda karena siklus dari tegangan PLN yang berubah-ubah, naik dan turun, seperti ditunjukkan pada gambar di bawah. Hal ini akan menjadi tolak ukur terhadap hasil pembacaan daya yang digunakan oleh sistem.

Tabel 1. Hasil pengukuran Tegangan Listrik menggunakan sensor tegangan ZMPT101B

\begin{tabular}{c|ccc}
\hline No & Tampilan Display Terminal 1 & Tampilan Display Terminal 2 & Tampilan Display Terminal 3 \\
\hline 1 & 217 VAC & 214 VAC & 217 VAC \\
2 & 220 VAC & 215 VAC & 220 VAC \\
3 & 218 VAC & 221 VAC & 221 VAC \\
4 & 215 VAC & 220 VAC & 220 VAC \\
5 & 217 VAC & 217 VAC & 217 VAC \\
6 & 218 VAC & 220 VAC & 221 VAC \\
7 & 217 VAC & 214 VAC & 217 VAC \\
\hline
\end{tabular}

Untuk pengukuran sensor arus (AC N25) menggunakan beban, yang digunakan adalah barang elektronik rumah tangga yaitu setrika, kipas angin dan rice cooker. Dari pengujian yang dilakukan, diperoleh hasil pengukuran seperti pada tabel di bawah ini.

Tabel 2. Hasil pengukuran arus menggunakan sensor arus AC N25

\begin{tabular}{l|lll}
\hline No & Setrika & Kipas angin & Rice cooker \\
\hline 1 & $1.36 \mathrm{~A}$ & $1.47 \mathrm{~A}$ & $1.02 \mathrm{~A}$ \\
2 & $1.36 \mathrm{~A}$ & $1.28 \mathrm{~A}$ & $1.02 \mathrm{~A}$ \\
3 & $1.36 \mathrm{~A}$ & $1.28 \mathrm{~A}$ & $1.02 \mathrm{~A}$ \\
4 & $1.36 \mathrm{~A}$ & $1.28 \mathrm{~A}$ & $1.02 \mathrm{~A}$ \\
5 & $1.36 \mathrm{~A}$ & $1.28 \mathrm{~A}$ & $1.02 \mathrm{~A}$ \\
6 & $1.36 \mathrm{~A}$ & $1.47 \mathrm{~A}$ & $1.02 \mathrm{~A}$ \\
7 & $1.36 \mathrm{~A}$ & $1.47 \mathrm{~A}$ & $1.02 \mathrm{~A}$ \\
\hline
\end{tabular}

Rangkaian sensor arus AC N25 sendiri menggunakan 4 resistor (2 buah $100 \mathrm{~K}$ ohm dan 2 buah $100 \mathrm{Ohm}$ ) dalam 1 buah sensor. Jadi ketiga sensor menggunakan 16 resistor ( 6 buah $100 \mathrm{~K}$ ohm dan 6 buah $100 \mathrm{Ohm}$ ) dengan membutuhkan tegangan $5 \mathrm{~V}$. Adapun skema rangkaian yang dibuat dapat dilihat pada Gambar 5 di bawah ini. 


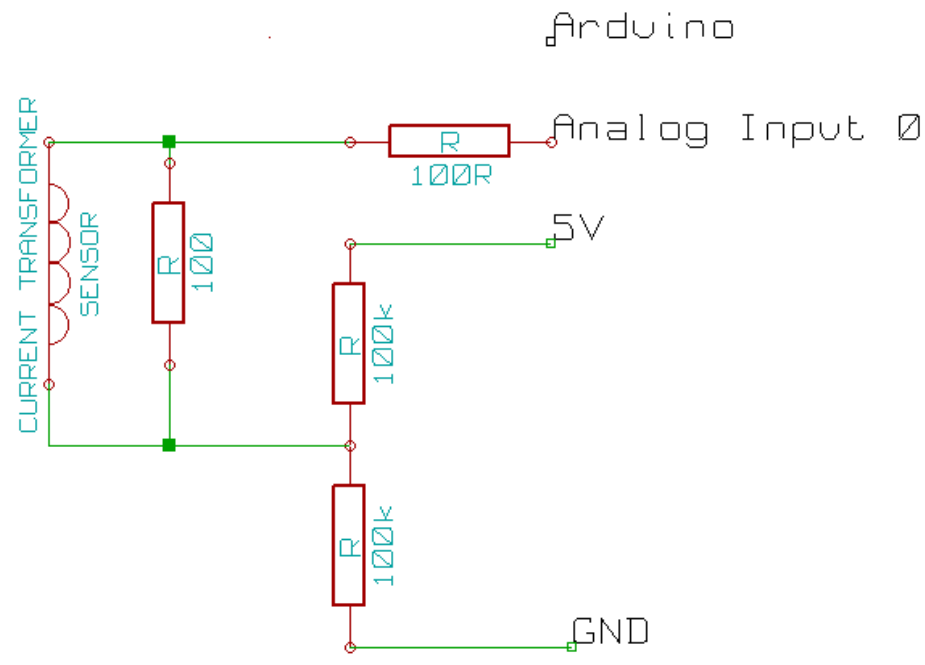

Gambar 5. Skema rangkaian sensor

Dalam simulasi yang dilakukan dalam penelitian ini, dapat dilihat skema perangkat yang terhubung pada Gambar 6 di bawah.

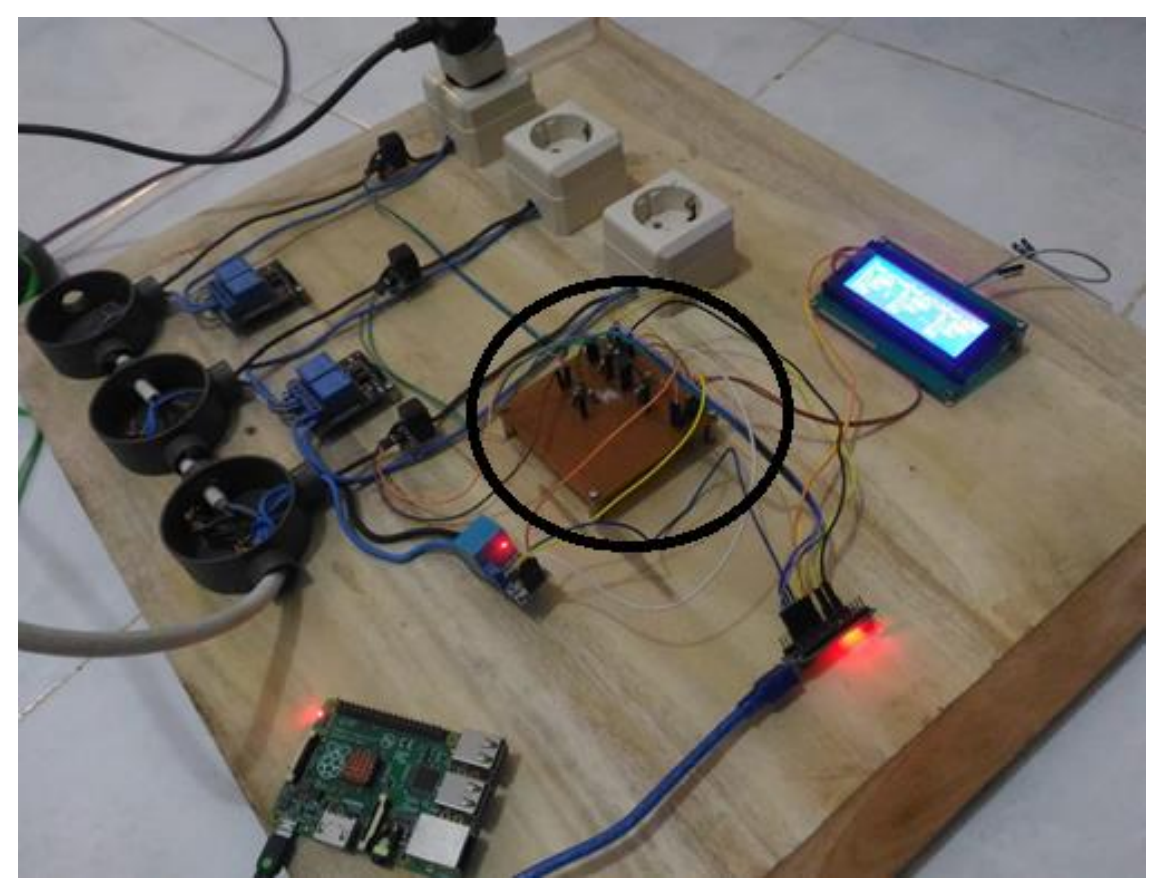

Gambar 6. Rangkaian perangkat pengukuran penggunaan energi listrik berbasis loT

Sementara itu, untuk mencari tegangan dan arus, secara berturutan, digunakan rumus sebagai berikut.

$$
\begin{aligned}
& V \text { out }=V \text { in } x\left(\frac{R \text { bottom }}{R \text { top }+R \text { bottom }}\right) \\
& V=I X R
\end{aligned}
$$


dimana $\mathrm{V}$ adalah arus, dan $\mathrm{R}$ adalah resistor.

Dari formula tersebut, maka diperoleh tegangan sebesar 2,5 V.

$$
\begin{aligned}
& V \text { out }=5 V x\left(\frac{100 k}{100 k+100 k}\right) \\
& V \text { out }=5 V x\left(\frac{100 k}{200 k}\right) \\
& \text { Vout }=2,5 \mathrm{~V}
\end{aligned}
$$

Diperoleh pula arus yang dibutuhkan sebesar $0.025 \mathrm{~A}$ atau $25 \mathrm{~mA}$.

$$
I=\frac{2,5 \mathrm{~V}}{100 \mathrm{ohm}}=0,025 \mathrm{~A}=25 \mathrm{~mA}
$$

Dengan demikian, diperoleh konsumsi daya oleh perangkat yang digunakan. Jumlah konsumsi daya kotak-kontak pintar pada rumah cerdas adalah pada sensor arus 0.125 Watt, sensor tegangan 0.001 Watt dan Arduino Nano 0.2 Watt. Dapat dilihat bahwa konsumsi daya dari perangkat ini adalah kecil, sehingga tidak mempengaruhi konsumsi daya dalam rumah itu sendiri. Dari proses pemantauan yang dilakukan, dapat diketahui rerata pemanfaatan perangkat listrik yang terhubung dengan kotak kontak pintar ini. Dengan pemantauan tersebut, maka dapat segera diketahui perangkat dalam rumah tangga yang sudah tidak berfungsi dengan baik lagi dilihat dari konsumsi dayanya yang tidak semestinya.

\section{SIMPULAN DAN SARAN}

Dari penelitian yang telah dilakukan, dapat diperoleh beberapa kesimpulan seperti yang dijabarkan sebagai berikut. Terdapat penurunan kemampuan yang dialami arus AC N25 dengan nilai perubahan rata-rata $1 \mathrm{~A}$ pada ketiga sensor. Perbedaan hasil pengukuran tegangan AC (220 VAC) yang dihasilkan sensor tegangan ZMPT101B, alat ukur Multimeter UT dan alat ukur digital multimeter kyoritsu adalah sebesar rentang 5 VAC, sehingga dapat disimpulkan bahwa alat yang dirancang sudah sesuai dengan tegangan yang ada. Jumlah konsumsi daya kotak-kontak pintar pada smarthome berbasis iot adalah pada sensor arus 0.125 Watt, sensor tegangan 0.001 Watt dan Arduino Nano 0.2 Watt. Perangkat yang dikembangkan telah mampu melakukan pembacaan terhadap tegangan dan arus dari perangkat-perangkat elektronik yang terhubung dengannya. Lebih jauh, perangkat ini dapat mendeteksi keabnormalan penggunaan energi listrik dari perangkat elektronik yang terhubung dengannya.

Namun demikian, sistem dengan perangkat kotak kontak pintar yang dikembangkan masih menggunakan pencermatan sederhana berbasiskan nilai ambang atas dan bawah dari penggunaan daya listrik oleh perangkat elektronik yang terhubung. Walaupun dapat memberi tanda sebuah perangkat tidak berfungsi sebagaimana layaknya, namun diperlukan sebuah pemantauan otomatis yang lebih baik untuk memberikan akurasi dan kecepatan proses yang lebih baik juga. Oleh sebab itu, perangkat ini dapat dikembangkan lebih lanjut dengan memanfaatkan metode-metode otomasi terkini untuk mengetahui dengan jauh lebih baik. Lebih jauh, dengan adanya penurunan kemampuan pada sensor AC N25, disarankan untuk menggunakan sensor lainnya dengan kemampuan yang sejenis dikarenakan sensor tersebut tidak baik untuk digunakan dalam jangka waktu lama. Kemudian dalam penelitian ini menggunakan modul dalam bentuk board yang cukup besar, sehingga ke depannya disarankan untuk membentuk suatu modul portable dari produk purwarupa terkait.

\section{UCAPAN TERIMAKASIH}

Ucapan terimakasih penulis tujukan kepada Kementerian Riset, Teknologi, dan Pendidikan Tinggi yang telah mendukung terlaksananya penelitian ini melalui pendanaan DRPM skim hibah penelitian pascasarjana. 


\section{DAFTAR PUSTAKA}

[1] "ASEAN Centre for Energy", "ASEAN Energy Review and Statistics 2013," 2013. [Online]. Available: http://www.aseanenergy.org/resources/publications/asean-energy-review-andstatistics-2013/. [Accessed: 01-Jul-2019].

[2] "ASEAN Centre for Energy", "The 5th ASEAN Energy Outlook," 2017. [Online]. Available: http://www.aseanenergy.org/resources/the-5th-asean-energy-outlook/. [Accessed: 01-Jul2019].

[3] C. Hildegardis, "Audit Performa Energi Pada Gedung Laboratorium Komputer \& Kantor Yayasan Pendidikan Tinggi Nusa Nipa," Universitas Atma Jaya Yogyakarta, 2013.

[4] S. Li, L. Da Xu, and S. Zhao, "The internet of things: a survey," Inf. Syst. Front., vol. 17, no. 2, pp. 243-259, Apr. 2015.

[5] S. Suresh and P. V. Sruthi, "A review on smart home technology," IC-GET 2015 - Proc. 2015 Online Int. Conf. Green Eng. Technol., pp. 1-3, 2016.

[6] B. Zhou et al., "Smart home energy management systems: Concept, configurations, and scheduling strategies," Renew. Sustain. Energy Rev., vol. 61, pp. 30-40, Aug. 2016.

[7] B. L. Risteska Stojkoska and K. V. Trivodaliev, "A review of Internet of Things for smart home: Challenges and solutions," J. Clean. Prod., vol. 140, pp. 1454-1464, Jan. 2017.

[8] S. S. I. Samuel, "A review of connectivity challenges in loT-smart home," 2016 3rd MEC Int. Conf. Big Data Smart City, ICBDSC 2016, pp. 364-367, 2016.

[9] T. Malche and P. Maheshwary, "Internet of Things (IoT) for building Smart Home System," pp. 65-70, 2017.

[10] I. W. Sutaya, "Alat Solar Tracker Berbasis Mikrokontroler 8 Bit ATMega8535," J. Pendidik. Teknol. dan Kejuru., vol. 12, no. 2, pp. 191-204, Jul. 2015.

[11] M. S. Gitakarma, "Alat Bantu Survey Bawah Air Menggunakan Amoba, Robot Berbasis ROV," JST (Jurnal Sains dan Teknol., vol. 3, no. 2, Jan. 2015.

[12] K. U. Ariawan, "Rancang Bangun Simulator Kontrol Lampu Rambu Lalu Lintas Berbasis PLC OMRON CPM1A," JST (Jurnal Sains dan Teknol., vol. 1, no. 1, Oct. 2015.

[13] C. Larman and V. R. Basili, "Iterative and incremental developments. a brief history," Computer (Long. Beach. Calif)., vol. 36, no. 6, pp. 47-56, Jun. 2003.

[14] Wikipedia, "Iterative and incremental development," 2019. [Online]. Available: https://en.wikipedia.org/wiki/lterative_and_incremental_development. [Accessed: 01-Jul-2019].

[15] The PHP Group, "PHP: Hypertext Preprocessor," 2019. [Online]. Available: https://php.net/. [Accessed: 01-Jul-2019].

[16] Raspberry Pi Foundation, "Raspbian," 2019. [Online]. Available: https://www.raspbian.org/. [Accessed: 01-Jul-2019].

[17] The Apache Software Foundation, "Apache HTTP Server Project," 2019. [Online]. Available: https://httpd.apache.org/. [Accessed: 01-Jul-2019]. 